\title{
Paracoccus marinus sp. nov., an adonixanthin diglucoside-producing bacterium isolated from coastal seawater in Tokyo Bay
}

Correspondence

Shams Tabrez Khan

shams-tabrez-khan@nite.go.jp

\author{
Shams Tabrez Khan, ${ }^{1}$ Shinichi Takaichi ${ }^{2}$ and Shigeaki Harayama ${ }^{1}$ \\ ${ }^{1}$ Biological Resource Center (NBRC), National Institute of Technology and Evaluation (NITE), \\ 2-5-8, Kazusakamatari, Kisarazu-shi, Chiba 292-0818, Japan \\ ${ }^{2}$ Biological Laboratory, Nippon Medical School, Kosugi-cho 2, Nakahara, Kawasaki 211-0063, \\ Japan
}

\begin{abstract}
Two novel marine, Gram-negative, non-motile, catalase- and oxidase-positive, aerobic bacteria were isolated from coastal seawater in Tokyo Bay. Analysis of almost-complete 16S rRNA gene sequences showed that the two isolates are members of the genus Paracoccus, sharing highest 16S rRNA gene sequence similarity (96.5\%) with Paracoccus aminophilus NBRC $16710^{\top}$. The DNA-DNA reassociation values between $P$. aminophilus NBRC $16710^{\top}$ and these isolates were only $10-20 \%$, in contrast to the high DNA relatedness between the two isolates (89\%). At least $1 \%(\mathrm{w} / \mathrm{v}) \mathrm{NaCl}$ was required for growth. Cellular fatty acid profiles revealed $\mathrm{C}_{18: 1} \omega 7 \mathrm{C}$ as the major component and $\mathrm{C}_{10: 0} 3-\mathrm{OH}$ as the major hydroxy fatty acid. Ubiquinone-10 was detected as the major respiratory quinone. The $\mathrm{G}+\mathrm{C}$ content of the genomic DNA of both strains was $69 \mathrm{~mol} \%$. On the basis of DNA-DNA hybridization data and physiological and chemotaxonomic characteristics, it is proposed that these strains should be placed in a novel species, Paracoccus marinus sp. nov. The type strain is KKL-A5 ${ }^{\top}\left(=\right.$ NBRC $100637^{\top}=\mathrm{CIP}$ $\left.108500^{\top}\right)$; KKL-B9 $(=$ NBRC 100640$)$ is a reference strain.
\end{abstract}

Many marine bacteria are difficult to cultivate because of their oligotrophic nature. To cultivate such bacteria, which may not be adapted for growth in nutrient-rich media, Button et al. (1993) used natural seawater (containing a very low concentration of organic carbon) as the growth medium. This technique was further improved to meet high-throughput culturing (Connon \& Giovannoni, 2002) and many novel microbial strains, including those that had previously been believed to be 'unculturable', have been isolated. The high-throughput culturing approach was used to study the microbial ecology of seawater in Tokyo Bay and two novel strains of the genus Paracoccus were isolated.

Seawater samples were collected from Kisarazu port on the east side of Tokyo Bay and total cell counts were analysed using 4',6-diamidino-2-phenylindole (DAPI) staining. The samples were diluted in sterile seawater to give 1-5 cells $\mathrm{ml}^{-1}$. Each $1 \mathrm{ml}$ diluted sample was dispensed into $2 \mathrm{ml}$ 96-deep-well plates, which were sealed with the 96well-plate cap and incubated at $20{ }^{\circ} \mathrm{C}$. After 1 week of incubation, microbial growth in each well was examined by

Abbreviation: DAPI, 4',6-diamidino-2-phenylindole.

The GenBank/EMBL/DDBJ accession numbers for the 16S rRNA gene sequences of strains $K K L-A 5^{\top}$ and $K K L-B 9$ are $A B 185957$ and AB185959, respectively.
DAPI staining using $100 \mu \mathrm{l}$ sample. Wells showing multiplication of microbes were used to inoculate quarter-strength marine agar 2216 (Difco) plates to isolate colony-forming bacteria. Colonies grown on the plates were subsequently subcultured and purified on the same medium. Two strains, KKL-A5 ${ }^{\mathrm{T}}$ and KKL-B9, were thus isolated and subjected to polyphasic characterization.

For routine cultivation, half-strength marine agar 2216 (HSMA) diluted with artificial seawater (Naigai Chemicals) at $25{ }^{\circ} \mathrm{C}$ was used. The KKL strains were stored at $-80{ }^{\circ} \mathrm{C}$ in artificial seawater with $20 \%(\mathrm{v} / \mathrm{v})$ glycerol for long-term preservation.

To determine the phylogenetic position of these strains, genomic DNA was extracted by using the Qiagen DNeasy Tissue kit according to the manufacturer's protocol and $16 \mathrm{~S}$ rRNA gene fragments were PCR-amplified using $20 \mathrm{ng}$ genomic DNA and a set of universal primers (27f and 1492r; Brosius et al., 1978). Amplified products were purified using the Qiagen PCR purification kit before sequencing, which was carried out using an ABI Big Dye Terminator Cycle Sequence kit (version 3.1) and an Applied Biosystems 3730 DNA Analyzer. A comparison of almost-complete 16S rRNA gene sequences of the two KKL strains using the dynamic programming algorithm (Needleman \& Wunsch, 1970; http://www.ebi.ac.uk/ emboss/align/) showed that the sequences were $99.9 \%$ 
similar to each other. A BLAST search showed that the novel strains are members of the genus Paracoccus. The 16S rRNA gene sequences of type strains of species of the genus Paracoccus with validly published names were retrieved from the DDBJ/EMBL/GenBank databases and pairwise comparisons were made between $16 \mathrm{~S}$ rRNA gene sequences of the KKL strains and those of the type strains. It was shown that, of all the sequences studied, that of Paracoccus aminophilus NBRC $16710^{\mathrm{T}}$ shared the highest $16 \mathrm{~S}$ rRNA gene sequence similarity $(96.5 \%)$ with the two strains. The $16 \mathrm{~S}$ rRNA gene sequences of the type strains and the KKL strains were multiply aligned using CLUSTAL_X (Thompson et al., 1997). Phylogenetic trees were inferred by using the neighbour-joining (Saitou \& Nei, 1987) and maximumlikelihood (Adachi \& Hasegawa, 1996) algorithms. The robustness of the phyletic lines was evaluated by bootstrap resampling analysis (Felsenstein, 1985) of 1000 replicates for neighbour-joining and 100 replicates for maximumlikelihood. As shown in Fig. 1, the KKL strains grouped with P. aminophilus NBRC $16710^{\mathrm{T}}$. Although the bootstrap value obtained for the node was low, the results of the phylogenetic analysis were congruent with those of pairwise alignments of $16 \mathrm{~S}$ rRNA gene sequences, identifying P. aminophilus NBRC $16710^{\mathrm{T}}$ as the closest relative. DNA-DNA hybridization was performed between the KKL strains and $P$. aminophilus NBRC $16710^{\mathrm{T}}$. Genomic DNA was extracted using the protocol of Minamisawa (1990) and the fluorometric method of Ezaki et al. (1989) was used for DNA-DNA hybridization in $50 \%$ formamide at $50{ }^{\circ} \mathrm{C}$. The DNA-DNA reassociation value between strains KKL-A $5^{\mathrm{T}}$ and KKL-B9 was $89 \%$; however, values between the KKL strains and $P$. aminophilus were considerably lower $(10-23 \%)$.

The $\mathrm{G}+\mathrm{C}$ content of chromosomal DNA was determined by the HPLC method of Mesbah et al. (1989). The G+C contents of both KKL strains were $69 \mathrm{~mol} \%$.
These strains were further tested for a number of key characters using standard procedures as described below. Colony morphology was observed on HSMA plates at $25{ }^{\circ} \mathrm{C}$. Four-day-old colonies were round, uniform, small (1-2 $\mathrm{mm})$ and dull orange in colour. Cell morphology from 3-day-old colonies on HSMA plates was observed under a transmission electron microscope (H7600; Hitachi) after negative staining with $1 \%(\mathrm{w} / \mathrm{v})$ phosphotungstic acid. Gram staining was performed as described by Cowan \& Steel (1993). The method described by Buck (1982) for the differentiation of Gram-positive and Gramnegative bacteria was also used. The KKL strains were Gram-negative, non-motile, short rods, measuring 0.5$0.8 \mu \mathrm{m}$ wide and $0.8-1.2 \mu \mathrm{m}$ long. Catalase activity was tested by mixing cells from colonies grown on HSMA plates with $3 \%(\mathrm{v} / \mathrm{v})$ hydrogen peroxide on a glass slide; oxidase activity was tested by spotting the cells on a cytochrome oxidase strip (Nissui Pharmaceuticals). Both strains tested positive for catalase and oxidase. The presence of carotenoid pigments was examined as described by Takaichi et al. (2006). The major carotenoid (nearly $80 \%$ of the total) was adonixanthin diglucoside (Takaichi et al., 2006). Growth at different temperatures (4, $10,15,20,25,30,35,37,40$ and $45^{\circ} \mathrm{C}$ ) was examined on HSMA plates and in marine broth 2216. The KKL strains grew optimally at $25-35{ }^{\circ} \mathrm{C}$ and very weakly at 10 and $37^{\circ} \mathrm{C}$. No growth was observed on plates incubated at 4,40 or $45{ }^{\circ} \mathrm{C}$. The ability to grow at different $\mathrm{pH}$ values was examined in marine broth 2216 (Difco) adjusted to a final $\mathrm{pH}$ with either $\mathrm{HCl}(\mathrm{pH} 4.0,5.0$ and 6.0) or $\mathrm{NaOH}$ $(\mathrm{pH}$ 8.0, 9.0 and 10.0). Both strains grew at $\mathrm{pH}$ 6.0-9.0; optimal growth was at $\mathrm{pH}$ 7.0-8.0. However, no growth was observed at $\mathrm{pH} 4.0,5.0$ or 10.0. The ability of the KKL strains to grow in different salinities was assessed in onefifth-strength LB medium ( $2 \mathrm{~g}$ Bacto tryptone and $1 \mathrm{~g}$ yeast extract per litre MilliQ water) with $0,1,2,3,4,5,6,7,10$,

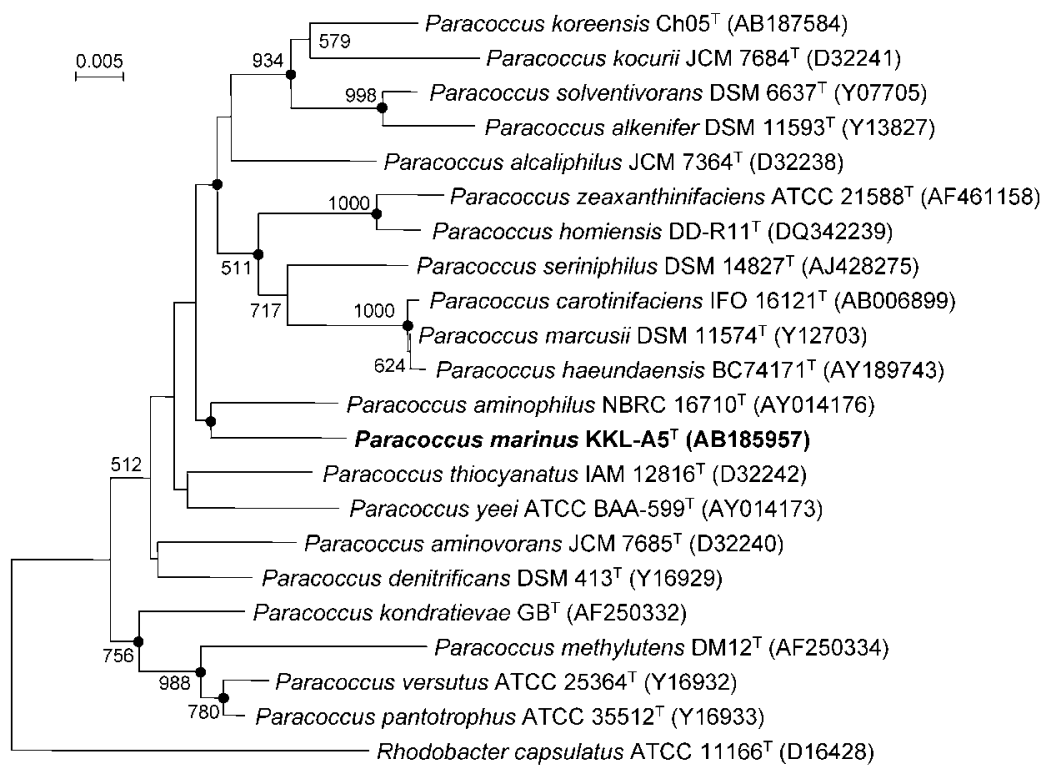

Fig. 1. Neighbour-joining tree based on almost-complete 16S rRNA gene sequences showing the phylogenetic relationship between strains KKL-A5 ${ }^{\top}$ and KKL-B9 (Paracoccus marinus sp. nov.) and related species. Bootstrap values of $\geqslant 500$ are shown at the nodes. Closed circles show the nodes that were also recovered in maximum-likelihood analysis. Bar, $0.005 K_{\text {nuc }}$. 
12 and $15 \%(w / v) ~ N a C l$. Strains grew in $1-4 \%(w / v) ~ N a C l$ (optimally in $2-3 \% \mathrm{NaCl}$ ); very weak or no growth was observed in one-fifth-strength $\mathrm{LB}$ without $\mathrm{NaCl}$ or supplemented with $5-15 \%(\mathrm{w} / \mathrm{v}) \mathrm{NaCl}$. Utilization of sodium nitrate $\left(7.8 \mathrm{~g} \mathrm{l}^{-1}\right)$, ammonium sulfate $\left(7.8 \mathrm{~g} \mathrm{l}^{-1}\right)$, sodium glutamate $\left(20 \mathrm{~g} \mathrm{l}^{-1}\right)$, Casamino acids $\left(10 \mathrm{~g} \mathrm{l}^{-1}\right.$; Difco) and peptone $\left(10 \mathrm{~g} \mathrm{l}^{-1}\right.$; Difco) as nitrogen sources was tested in medium $\mathrm{N}$ (artificial seawater containing $1.0 \mathrm{~g}$ glucose $1^{-1}$ and $0.2 \mathrm{~g} \mathrm{NaHCO}_{3} \mathrm{l}^{-1}$, pH 7.0). Only peptone was utilized by the KKL strains. Utilization of different carbon sources was tested by using artificial seawater supplemented with casein hydrolysate $(10 \mathrm{mg}$ $\mathrm{l}^{-1}$; Fluka) and yeast extract $\left(0.1 \mathrm{~g} \mathrm{l}^{-1}\right)$ and the following substrates, each at a concentration of $0.2 \%(\mathrm{w} / \mathrm{v})$ : Darabinose, D-fructose, D-galactose, D-glucose, $\alpha$-D-lactose, maltose, D-mannose, sucrose, trehalose, acetate, formate, lactate, pyruvate, propionate, succinate, arginine, asparagine, ethanol, myo-inositol, D-mannitol and D-sorbitol (Ruiz-Ponte et al., 1998). The KKL strains assimilated relatively few carbon sources, as listed in the species description. Degradation of starch, casein, chitin, DNA, gelatin and Tweens 20,40 and 80 and the reduction of nitrate and nitrite were tested according to the protocols of Cowan \& Steel (1993). Both strains degraded Tween 20, but were negative for the degradation of starch, casein, chitin, DNA, gelatin and Tweens 40 and 80 and for the reduction of nitrate and nitrite. API 20NE strips (bioMérieux) and GN2 microplates (Biolog) were used to characterize the strains according to the manufacturers' instructions except that inocula were prepared according to Rüger \& Krambeck (1994). Biolog microplates and API strips were analysed after 3 and 2 days incubation at $25{ }^{\circ} \mathrm{C}$, respectively. The strains were not able to utilize any substrate provided within the Biolog GN2 microplates. The strains also tested negative for all tests included in the API 20NE strips (reduction of nitrate and nitrite, production of indole from tryptophan, production of acid from glucose and the presence of urease, $\beta$-galactosidase and $\beta$-glucosidase).

For chemotaxonomic characterization, fatty acid analysis and quinone analysis was performed. Strains were cultivated for 3 days on marine agar 2216 at $25{ }^{\circ} \mathrm{C}$ before cells were harvested for fatty acid analysis using the Sherlock Microbial Identification System according to the MIDI instructions (Sasser, 1990). The cellular fatty acid profile of the KKL strains was characterized by a large proportion of $\mathrm{C}_{18: 1} \omega 7 c(85-87 \%)$ with $\mathrm{C}_{10: 0} 3-\mathrm{OH}(2 \%)$ as the major hydroxy fatty acid. Other fatty acids detected were $\mathrm{C}_{18: 0}(4-5 \%), \mathrm{C}_{17: 0}(1-2 \%), \mathrm{C}_{19: 0}$ 10-methyl (2\%) and an unknown fatty acid of equivalent chain-length $11.79(2 \%)$. The following fatty acids were detected in trace amounts: $\mathrm{C}_{16: 0}, \mathrm{C}_{19: 0}, \mathrm{C}_{17: 1} \omega 8 c, \mathrm{C}_{18: 0} 3-\mathrm{OH}$ and $\mathrm{C}_{20: 1} \omega 07 c$. This fatty acid profile is characteristic of the Alphaproteobacteria, including members of the genus Paracoccus (Kelly et al., 2006).

The protocol of Nakagawa \& Yamasato (1993) was used for analysis of isoprenoid quinones. Ubiquinone-10 was found as the major quinone in both strains.
Four members of the genus Paracoccus that shared the highest pairwise $16 \mathrm{~S}$ rRNA gene sequence similarities with the two isolates, namely $P$. aminophilus (96.5\%), Paracoccus seriniphilus (96.2\%), Paracoccus zeaxanthinifaciens $(96.1 \%)$ and Paracoccus koreensis (96\%), were selected for comparison of biochemical, physiological and chemotaxonomic characters with those of the KKL strains (Table 1). Taking into account the physiological and molecular properties of the KKL strains, it is proposed that these two strains should be classified as representatives of a novel species of the genus Paracoccus. The name Paracoccus marinus sp. nov. is proposed.

\section{Description of Paracoccus marinus sp. nov.}

Paracoccus marinus (ma.ri'nus. L. masc. adj. marinus of or belonging to the sea, marine).

Gram-negative, aerobic, non-motile, short rod-shaped cells, $0.5-0.8 \mu \mathrm{m}$ wide and $0.8-1.2 \mu \mathrm{m}$ long. Colonies on

Table 1. Differential characteristics of strains $K K L-A 5^{\top}$ and KKL-B9 (Paracoccus marinus sp. nov.) and related species

Taxa: 1, strains KKL-A5 ${ }^{\mathrm{T}}$ and KKL-B9 (P. marinus sp. nov.; data from this study); 2, P. aminophilus (Urakami et al., 1990); 3, P. seriniphilus (Pukall et al., 2003); 4, P. zeaxanthinifaciens (Berry et al., 2003); 5, P. koreensis (La et al., 2005). -, Negative; +, positive; $\mathrm{W}+$, weakly positive; NA, no data available.

\begin{tabular}{|c|c|c|c|c|c|}
\hline Characteristic & 1 & 2 & 3 & 4 & 5 \\
\hline Colony colour ${ }^{*}$ & DO & $\mathrm{W}-\mathrm{LY}$ & None & YO & $\mathrm{W}$ \\
\hline Major pigment type $\dagger$ & $\mathrm{AD}$ & None & None & $\mathrm{ZA}$ & None \\
\hline Nitrate reduction & - & + & + & - & - \\
\hline Nitrite reduction & - & - & - & - & + \\
\hline \multicolumn{6}{|l|}{ Growth at/in: } \\
\hline $40{ }^{\circ} \mathrm{C}$ & - & - & - & + & NA \\
\hline $37{ }^{\circ} \mathrm{C}$ & $\mathrm{w}+$ & - & + & + & + \\
\hline $0 \% \mathrm{NaCl}$ & - & + & - & $\mathrm{NA}$ & $\mathrm{NA}$ \\
\hline $3 \% \mathrm{NaCl}$ & + & $\mathrm{w}+$ & + & + & NA \\
\hline $6 \% \mathrm{NaCl}$ & - & NA & + & + & NA \\
\hline \multicolumn{6}{|l|}{ Growth on: } \\
\hline Methanol & NA & - & NA & NA & NA \\
\hline Mannitol & - & - & + & + & - \\
\hline Inositol & - & - & + & + & - \\
\hline Fructose & + & - & + & NA & NA \\
\hline Urease & - & - & - & + & - \\
\hline$\beta$-Galactosidase & - & NA & + & + & - \\
\hline$\beta$-Glucosidase & - & NA & - & + & - \\
\hline \multicolumn{6}{|l|}{ Major 3-OH fatty acids } \\
\hline $\mathrm{C}_{10: 0} 3-\mathrm{OH}$ & + & + & + & + & + \\
\hline $\mathrm{C}_{14: 0} 3-\mathrm{OH}$ & - & + & - & - & - \\
\hline $\mathrm{C}_{18: 0} 3-\mathrm{OH}$ & + & - & - & + & - \\
\hline $\begin{array}{l}\text { DNA G }+ \text { C content } \\
(\mathrm{mol} \%)\end{array}$ & 69 & 63 & 63 & $67-68$ & 69 \\
\hline
\end{tabular}

${ }^{\star}$ DO, Dull orange; LY, light yellow; w, white; YO, yellow-orange. $\dagger \mathrm{AD}$, Adonixanthin diglucoside; $\mathrm{ZA}$, zeaxanthin. 
marine agar 2216 are circular, convex, smooth and dull orange in colour. Major carotenoid is adonixanthin diglucoside. Catalase- and oxidase-positive, but negative for $\beta$-glucosidase and $\beta$-galactosidase. Growth occurs between 10 and $35{ }^{\circ} \mathrm{C}$ (optimum $25-35{ }^{\circ} \mathrm{C}$ ) and at $\mathrm{pH} 6-$ 9 (optimum $\mathrm{pH} 7.0-8.0) . \mathrm{NaCl}(1-4 \%, \mathrm{w} / \mathrm{v})$ is required for growth (optimum 2-3\%). Growth does not occur at $\mathrm{NaCl}$ concentrations of $5 \%(\mathrm{w} / \mathrm{v})$ and higher. Utilizes peptone, but not ammonium sulfate, sodium glutamate, sodium nitrate or Casamino acids as nitrogen sources. D-Fructose, D-galactose, D-glucose, lactate, pyruvate and asparagine are utilized as carbon sources, but D-arabinose, $\alpha$-D-lactose, maltose, D-mannose, sucrose, trehalose, acetate, formate, propionate, succinate, arginine, ethanol, myo-inositol, Dmannitol and D-sorbitol are not utilized. Starch, gelatin, casein, chitin, DNA, aesculin, urea, arginine and Tweens 40 and 80 are not hydrolysed, but Tween 20 is hydrolysed. Indole is not produced from tryptophan and acid is not produced from glucose. Nitrate and nitrite are not reduced. The major fatty acid is $\mathrm{C}_{18: 1} \omega 7 c, \mathrm{C}_{10: 0} 3-\mathrm{OH}$ is present as the major hydroxy fatty acid component. Ubiquinone-10 is the major respiratory quinone.

The type strain is KKL-A5 ${ }^{\mathrm{T}}\left(=\mathrm{NBRC} 100637^{\mathrm{T}}=\mathrm{CIP}\right.$ $108500^{\mathrm{T}}$ ), isolated from the seawater of Kisarazu port, Tokyo Bay; a reference strain, KKL-B9 (=NBRC 100640), was isolated from the same source. The DNA G+C content of the type strain is $69 \mathrm{~mol} \%$.

\section{Acknowledgements}

This work was supported by the New Energy and Industrial Technology Development Organization (NEDO grant no. 04000182-0). The authors would like to thank Motoyuki Ohuchi for technical assistance.

\section{References}

Adachi, J. \& Hasegawa, M. (1996). MOLPHY Version 2.3 - Programs for Molecular Phylogenetics Based on Maximum Likelihood. Computer Science Monograph no. 28. Tokyo: Institute of Statistical Mathematics.

Berry, A., Janssens, D., Hümbelin, M., Jore, J. P., Hoste, B., Cleenwerck, I., Vancanneyt, M., Bretzel, W., Mayer, A. F. \& other authors (2003). Paracoccus zeaxanthinifaciens sp. nov., a zeaxanthinproducing bacterium. Int J Syst Evol Microbiol 53, 231-238.

Brosius, J., Palmer, M. L., Kennedy, P. J. \& Noller, H. F. (1978). Complete nucleotide sequence of a $16 \mathrm{~S}$ ribosomal RNA gene from Escherichia coli. Proc Natl Acad Sci U S A 75, 4801-4805.

Buck, J. D. (1982). Nonstaining ( $\mathrm{KOH})$ method for determination of Gram reactions of marine bacteria. Appl Environ Microbiol 44, 992-993.

Button, D. K., Schut, F., Ouang, P., Martin, R. \& Robertson, B. R. (1993). Viability and isolation of marine bacteria by dilution culture: theory procedures and initial results. Appl Environ Microbiol 59, 881-891.

Connon, S. A. \& Giovannoni, S. J. (2002). High-throughput methods for culturing microorganisms in very-low-nutrient media yield diverse new marine isolates. Appl Environ Microbiol 68, 3878-3885.
Cowan, S. T. \& Steel, K. J. (1993). Manual for the Identification of Medical Bacteria, 3rd edn. Edited and revised by G. I. Barrow \& R. K. A. Feltham. Cambridge: Cambridge University Press.

Ezaki, T., Hashimoto, Y. \& Yabuuchi, E. (1989). Fluorometric deoxyribonucleic acid-deoxyribonucleic acid hybridization in microdilution wells as an alternative to membrane filter hybridization in which radioisotopes are used to determine genetic relatedness among bacterial strains. Int J Syst Bacteriol 39, 224-229.

Felsenstein, J. (1985). Confidence limits on phylogenies: an approach using the bootstrap. Evolution 39, 783-791.

Kelly, D. P., Rainey, F. A. \& Wood, A. P. (2006). The genus Paracoccus. In The Prokaryotes. A Handbook on the Biology of Bacteria, 3rd edn, vol. 5, pp. 232-249. Edited by M. Dworkin, S. Falkow, E. Rosenberg, K. H. Schleifer \& E. Stackebrandt. New York: Springer.

La, H.-J., Im, T.-W., Ten, L. N., Kang, S. M., Shin, D.-Y. \& Lee, S.-T. (2005). Paracoccus koreensis sp. nov., isolated from anaerobic granules in an upflow anaerobic sludge blanket (UASB) reactor. Int J Syst Evol Microbiol 55, 1657-1660.

Mesbah, M., Premachandran, U. \& Whitman, W. B. (1989). Precise measurement of the $\mathrm{G}+\mathrm{C}$ content of deoxyribonucleic acid by high-performance liquid chromatography. Int J Syst Bacteriol 39, 159-167.

Minamisawa, K. (1990). Division of rhizobitoxine-producing and hydrogen-uptake positive strains of Bradyrhizobium japonicum by nifDKE sequence divergence. Plant Cell Physiol 31, 81-89.

Nakagawa, Y. \& Yamasato, K. (1993). Phylogenetic diversity of the genus Cytophaga revealed by $16 \mathrm{~S}$ rRNA sequencing and menaquinone analysis. J Gen Microbiol 139, 1155-1161.

Needleman, S. B. \& Wunsch, C. D. (1970). A general method applicable to the search for similarities in the amino acid sequence of two proteins. J Mol Biol 48, 443-453.

Pukall, R., Laroche, M., Kroppenstedt, R. M., Schumann, P., Stackebrandt, E. \& Ulber, R. (2003). Paracoccus seriniphilus sp. nov., an L-serine-dehydratase-producing coccus isolated from marine bryozoan Bugula plumosa. Int J Syst Evol Microbiol 53, 443-447.

Rüger, H.-J. \& Krambeck, H.-J. (1994). Evaluation of the BIOLOG substrate metabolism system for classification of marine bacteria. Syst Appl Microbiol 17, 281-288.

Ruiz-Ponte, C., Cilia, V., Lambert, C. \& Nicolas, J. L. (1998). Roseobacter gallaeciensis sp. nov., a new marine bacterium isolated from rearings and collectors of the scallop Pecten maximus. Int J Syst Bacteriol 48, 537-542.

Saitou, N. \& Nei, M. (1987). The neighbor-joining method: a new method for reconstructing phylogenetic trees. Mol Biol Evol 4, 406-425.

Sasser, M. (1990). Identification of bacteria by gas chromatography of cellular fatty acids, MIDI Technical Note 101. Newark, DE: MIDI Inc. http://www.midi-inc.com/media/pdfs/TechNote_101.pdf

Takaichi, S., Maoka, T., Akimoto, N., Khan, S. T. \& Harayama, S. (2006). Major carotenoid from Paracoccus schoinia NBRC $100637^{\mathrm{T}}$ is adonixanthin diglucoside. J Nat Prod 69, 1823-1825.

Thompson, J. D., Gibson, T. J., Plewniak, F., Jeanmougin, F. \& Higgins, D. G. (1997). The CLUSTAL_X windows interface: flexible strategies for multiple sequence alignment aided by quality analysis tools. Nucleic Acids Res 25, 4876-4882.

Urakami, T., Araki, H., Oyanagi, H., Suzuki, K. \& Komagata, K. (1990). Paracoccus aminophilus sp. nov. and Paracoccus aminovorans sp. nov., which utilize $\mathrm{N}, \mathrm{N}$-dimethylformamide. Int J Syst Bacteriol 40, 287-291. 